\title{
The role of foreign investment in U.S. infrastructure: Opportunities and challenges ahead
}

\author{
Iordanis Petsas ${ }^{1, *} \cdot$ Sofia M. Vidalis ${ }^{2}$ \\ ${ }^{1}$ Department of Economics and Finance, The Arthur J. Kania School of Manage- \\ ment, University of Scranton, Scranton, PA, USA \\ ${ }^{2}$ Department of Civil Engineering/Structural Design \& Construction Engineering \\ Technology, Penn State Harrisburg, Harrisburg, PA, USA
}

Received: 29 October 2019

Revised: 7 January 2020

Accepted: 7 January 2020

\begin{abstract}
The U.S. infrastructure has been issued a grade of D+ from the American Society of Civil Engineers because of the low funding for new construction, maintenance, and repair. It is now reaching the end of its useful life and cost estimates have reached as high as \$3.6-trillion. The public infrastructure investment is at $2.4 \%$ of GDP, which is half of what it was 50-years ago. The U.S. has explored new ways to finance its infrastructure because of funding uncertainty. Investments such as, pensions, foreign investments, and sovereign wealth funds, manage trillions in assets and are forecasted to grow. This paper presents an overview of infrastructure funding and identifies possible approaches in addressing long-term financial needs with foreign capital partnership.
\end{abstract}

Keywords: sovereign wealth funds; infrastructure; foreign investment JEL Classification Codes: F21, H54, H72, H74, L90

\section{Introduction}

Infrastructure is the foundation that joins the nation's business, communities, and citizens. The U.S. was once known for its modern infrastructure in the world, today it is failing to keep pace with the current and expanding needs of the nation. Every four years the American Society of Civil Engineers (ASCE) offers a complete assessment of the nation's grade on infrastructure. These reported assessments are written by professional civil engineers from the industry and academia across the United States. In 2017, it was reported by the ASCE that the U.S. received an overall grade point average of D+ on the overall infrastructure, a slight rise from 2010's GPA of D (ASCE, 2017). ASCE uses a simple A to F school report card format in order to assign grades for current infrastructure. It is estimated that $\$ 4.59$ trillion needs to be invested in

\footnotetext{
*Corresponding author. E-mail: iordanis.petsas@scranton.edu.

Citation: Petsas, I., and Vidalis, S. M. (2020) The role of foreign investment in U.S. infrastructure: Opportunities and challenges ahead, Economics and Business Letters, 9(3), 157-166.
}

DOI: $10.17811 /$ ebl.9.3.2020.157-166 
Table 1. Percent Government Budget Spent by Agency (2016 - 2022).

\begin{tabular}{|c|c|c|c|c|c|c|c|}
\hline \multirow{2}{*}{ Agency } & \multicolumn{7}{|c|}{ Percent from Budget Spent } \\
\hline & 2016 & 2017 & 2018 & 2019 & 2020 & 2021 & 2022 \\
\hline National Defense & $15.71 \%$ & $15.27 \%$ & $15.08 \%$ & $14.53 \%$ & $14.02 \%$ & $13.58 \%$ & $13.06 \%$ \\
\hline International Affairs & $1.27 \%$ & $1.34 \%$ & $1.49 \%$ & $1.21 \%$ & $1.22 \%$ & $1.22 \%$ & $1.21 \%$ \\
\hline General Science, Space, and Technology & $0.80 \%$ & $0.77 \%$ & $0.78 \%$ & $0.75 \%$ & $0.72 \%$ & $0.70 \%$ & $0.67 \%$ \\
\hline Energy & $0.13 \%$ & $0.18 \%$ & $0.14 \%$ & $0.12 \%$ & $0.13 \%$ & $0.12 \%$ & $0.11 \%$ \\
\hline Natural Resources and Environment & $1.06 \%$ & $1.03 \%$ & $1.07 \%$ & $1.02 \%$ & $0.99 \%$ & $0.95 \%$ & $0.92 \%$ \\
\hline Agriculture & $0.94 \%$ & $0.48 \%$ & $0.52 \%$ & $0.49 \%$ & $0.54 \%$ & $0.49 \%$ & $0.46 \%$ \\
\hline Commerce and Housing Credit & $0.18 \%$ & $-0.37 \%$ & $-0.02 \%$ & $0.05 \%$ & $0.08 \%$ & $0.12 \%$ & $0.16 \%$ \\
\hline Transportation & $2.27 \%$ & $2.25 \%$ & $2.29 \%$ & $2.21 \%$ & $1.97 \%$ & $2.04 \%$ & $1.93 \%$ \\
\hline Community and Regional Development & $0.45 \%$ & $0.52 \%$ & $0.49 \%$ & $0.48 \%$ & $0.47 \%$ & $0.45 \%$ & $0.43 \%$ \\
\hline Education, Training, Employment, and Social Services & $2.78 \%$ & $3.62 \%$ & $2.64 \%$ & $2.63 \%$ & $2.55 \%$ & $2.51 \%$ & $2.40 \%$ \\
\hline Health & $12.99 \%$ & $13.15 \%$ & $13.51 \%$ & $13.36 \%$ & $13.38 \%$ & $13.12 \%$ & $12.99 \%$ \\
\hline Medicare & $15.21 \%$ & $14.71 \%$ & $14.16 \%$ & $14.84 \%$ & $15.15 \%$ & $15.48 \%$ & $16.38 \%$ \\
\hline Income Security & $13.20 \%$ & $12.65 \%$ & $12.49 \%$ & $12.23 \%$ & $11.83 \%$ & $11.50 \%$ & $11.18 \%$ \\
\hline Social Security & $23.16 \%$ & $23.32 \%$ & $24.52 \%$ & $24.57 \%$ & $24.59 \%$ & $24.65 \%$ & $24.58 \%$ \\
\hline Veterans Benefits and Services & $4.12 \%$ & $4.32 \%$ & $4.60 \%$ & $4.47 \%$ & $4.53 \%$ & $4.50 \%$ & $4.43 \%$ \\
\hline Administration of Justice & $1.42 \%$ & $1.58 \%$ & $1.77 \%$ & $1.39 \%$ & $1.35 \%$ & $1.31 \%$ & $1.26 \%$ \\
\hline General Government & $0.65 \%$ & $0.62 \%$ & $0.65 \%$ & $0.62 \%$ & $0.60 \%$ & $0.58 \%$ & $0.56 \%$ \\
\hline Net Interest & $6.04 \%$ & $6.74 \%$ & $7.63 \%$ & $8.45 \%$ & $9.21 \%$ & $9.85 \%$ & $10.30 \%$ \\
\hline Allowances & $0.00 \%$ & $0.10 \%$ & $-1.28 \%$ & $-1.17 \%$ & $-1.15 \%$ & $-1.13 \%$ & $-1.09 \%$ \\
\hline Undistributed Offsetting Receipts & $-2.40 \%$ & $-2.28 \%$ & $-2.52 \%$ & $-2.25 \%$ & $-2.15 \%$ & $-2.03 \%$ & $-1.94 \%$ \\
\hline Total & $3,972,912$ & $4,096,056$ & $4,144,717$ & $4,401,862$ & $4,675,221$ & $4,941,680$ & $5,261,012$ \\
\hline Total Percentage & $100 \%$ & $100 \%$ & $100 \%$ & $100 \%$ & $100 \%$ & $100 \%$ & $100 \%$ \\
\hline
\end{tabular}

Source: White House (2019).

America's infrastructure by 2025 in order to raise its GPA in terms of infrastructure, operations, maintenance, and public safety (ASCE, 2017). During the 2019 fiscal year, the U.S. government had spent about $\$ 4.4$ trillion. Out of this, only $2.21 \%$ was spent on transportation construction and maintenance, less than previous fiscal years, as seen in Table 1. Social Security, National Defense, and Medicare continue to be the top three agencies where most of the government budget is distributed. This is not projected to change in the next eight years (White House, 2019). ${ }^{1}$

The main challenge that the U.S. is facing is how to best finance its overall infrastructure cost. Overcoming this challenge and infrastructure bottleneck would boost long-term economic growth (ASCE, 2017).

One avenue to finance its infrastructure cost is through foreign direct investment. Since the mid-1980s, policies were pursued by governments around the world to boost private sector participation in the delivery and financing of infrastructure services (Kirkpatrick, et. al., 2006). However, investing in improving infrastructure may be important for attracting investments such as Foreign Direct Investment (FDI) in the U.S. This can bring more benefits such as providing funds to build a project, but it can also have some drawbacks like security. A particular type of FDI is channeled through Sovereign Wealth Funds (SWFs). SWFs are not the only avenue through which sovereign entities make foreign private investments. Another way is through the investment in foreign entities which is purchases by state-owned enterprises. ${ }^{2}$ There is no systematic work or conceptual framework to create a system of checks and balances to make sure that the SWFs do not undermine macroeconomic management (Balin, 2008).

This paper offers new insights regarding the current issues of the U.S. infrastructure. Its main contribution is the exploration of new avenues of funding the U.S. infrastructure such as SWFs. The paper describes the challenges and concerns related to the U.S. infrastructure funding.

The remaining of the paper is organized as follows: Section two of the paper discusses the composition and current issues of the U.S. infrastructure funding. Section three provides an overview of SWFs and their role in U.S. infrastructure and economic growth, while section four

\footnotetext{
${ }^{1}$ Among the 34 countries in the Organization for Economic Co-operation and Development (OECD), the U.S. consistently ranks last or second to last in transportation infrastructure spending as a percentage of GDP. The remaining developed world spends, on average, 52.7\% more of its GDP on transportation infrastructure than the U.S. (Council on Foreign Relations, 2012).

${ }^{2}$ Examples of state-owned enterprises include the acquisition of Peninsular and Oriental Steam Navigation Company $(\mathrm{P} \& \mathrm{O})$ by the state-owned Dubai Ports World Corporation and the purchase of IBM's computing business by the Chinese government-controlled Lenovo Group.
} 
Figure 1. State, Local Government, and Federal Infrastructure Spending, 1956 - 2017. Billions of 2017 Dollars

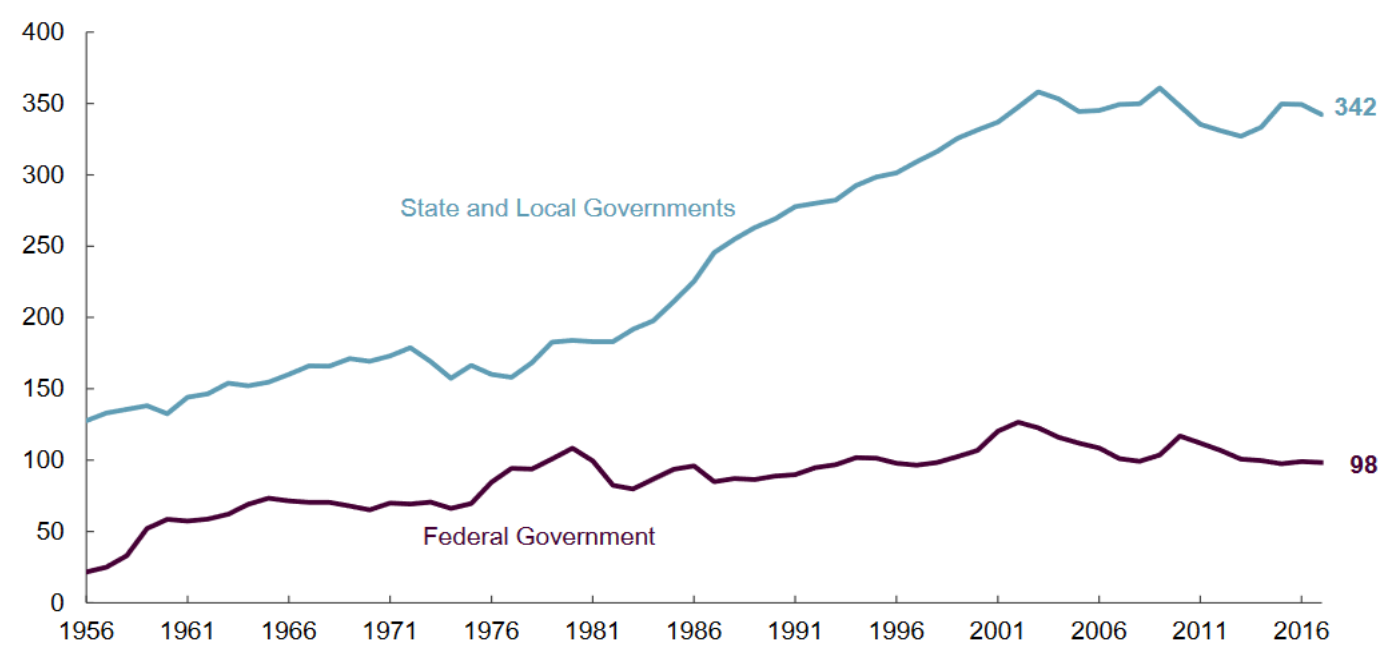

Source: CBO (2018). Notes: Local and state infrastructure spending is gross of loan subsidies and federal grants. These subsidies and loans are calculated as federal spending. Public infrastructure includes spending on rail, highways, mass transit, water transportation, water resources, aviation, and water utilities. An infrastructure-specific index was used to adjust annual values in dollars that accounted for fluctuations in the prices of goods and services spent for infrastructure.

outlines the opportunities and concerns related to foreign investment for U.S. infrastructure. Lastly, section five offers concluding remarks and recommendation on how U.S. can better finance its infrastructure.

\section{The composition and current issues of the U.S. infrastructure funding}

The serious concerns about the U.S. infrastructure were not made public until the collapse of Interstate 35 Bridge in Minneapolis during 2007. An evaluation of the bridge was made in 2001, which reported that the bridge had preliminary signs of fatigue on the steel truss section (Sander and Saulny, 2007).

According to the most recent report by the Congressional Budget Office (CBO), federal, state, and local government spending on transportation and water infrastructure totaled \$440-billion in 2016, as seen in Figure 1. State and local governments provided \$342-billion while federal government accounted for \$98-billion. Construction costs for several types of transportation infrastructure rose rapidly from 2003 to 2007. In addition, public spending, as a share of GDP, on transportation and water infrastructure decreased to $2.3 \%$ in 2017. It has remained within the range of $2.3-3.1$ in the past six decades, as seen in Figure $2 .^{3}$

About $97 \%$ of the nation's highways and roads are owned by local and state governments. Local and state governments supply about $75 \%$ of public funding for transportation and water infrastructure (e.g. U.S. municipal bond markets) that comes from State Highway Funds. State Highway Funds are received from a federal fuel tax of around 18.4-cents per gallon on gasoline and 24.4-cents per gallon of diesel fuel. These funds are used to build and maintain the U.S. highway system (EIA, 2019). However, the fuel efficiency of American drivers have shot up in recent years. It is estimated that in 2025 , by law, that vehicles will have to run at an average efficiency of 54.5-miles per gallon.

The other remaining $25 \%$ of the funding is funded by the federal government. These are mainly generated from trust funds and grants. There is a limit on the amount and number of

\footnotetext{
${ }^{3}$ This infrastructure spending has been increased by major legislation, such as the enacting of the American Recovery and Reinvestment Act of 2009 (CBO, 2018).
} 
Figure 2. Public Spending on Transportation and Water Infrastructure as a Share of GDP.

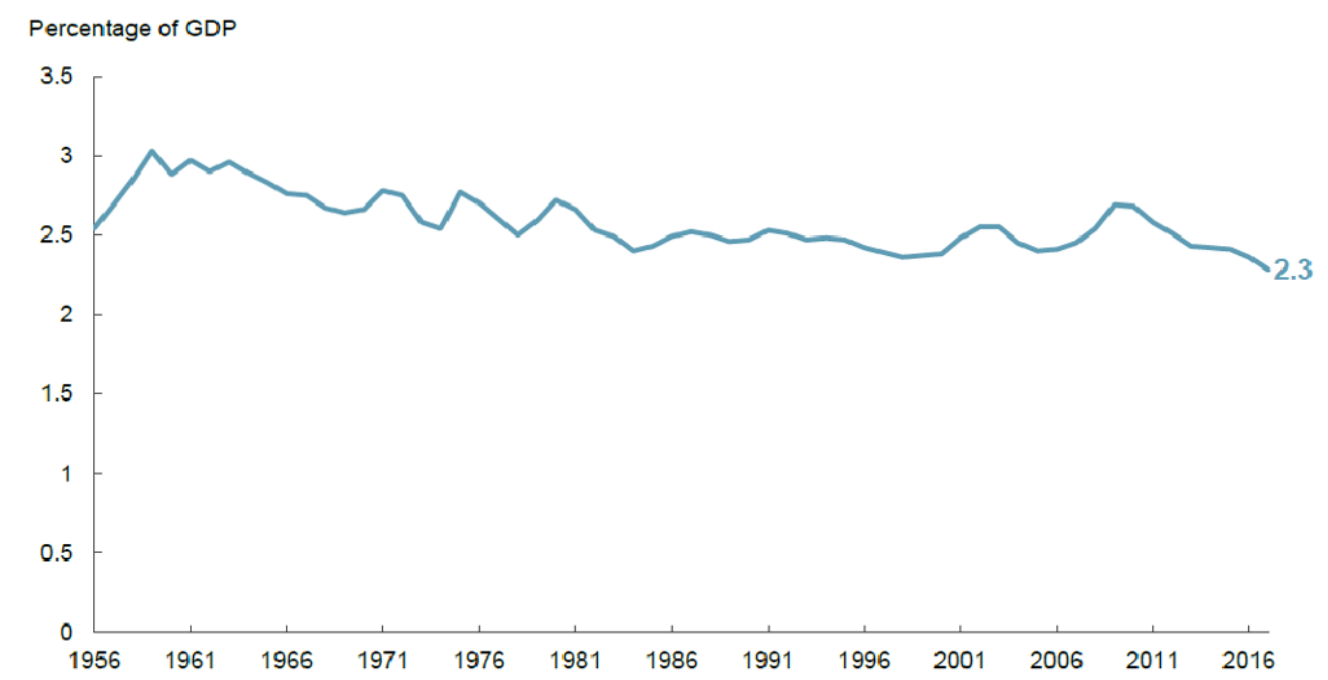

Source: CBO (2018).

Figure 3. U.S. Current Account and Net International Investment Position, 1976-2012.

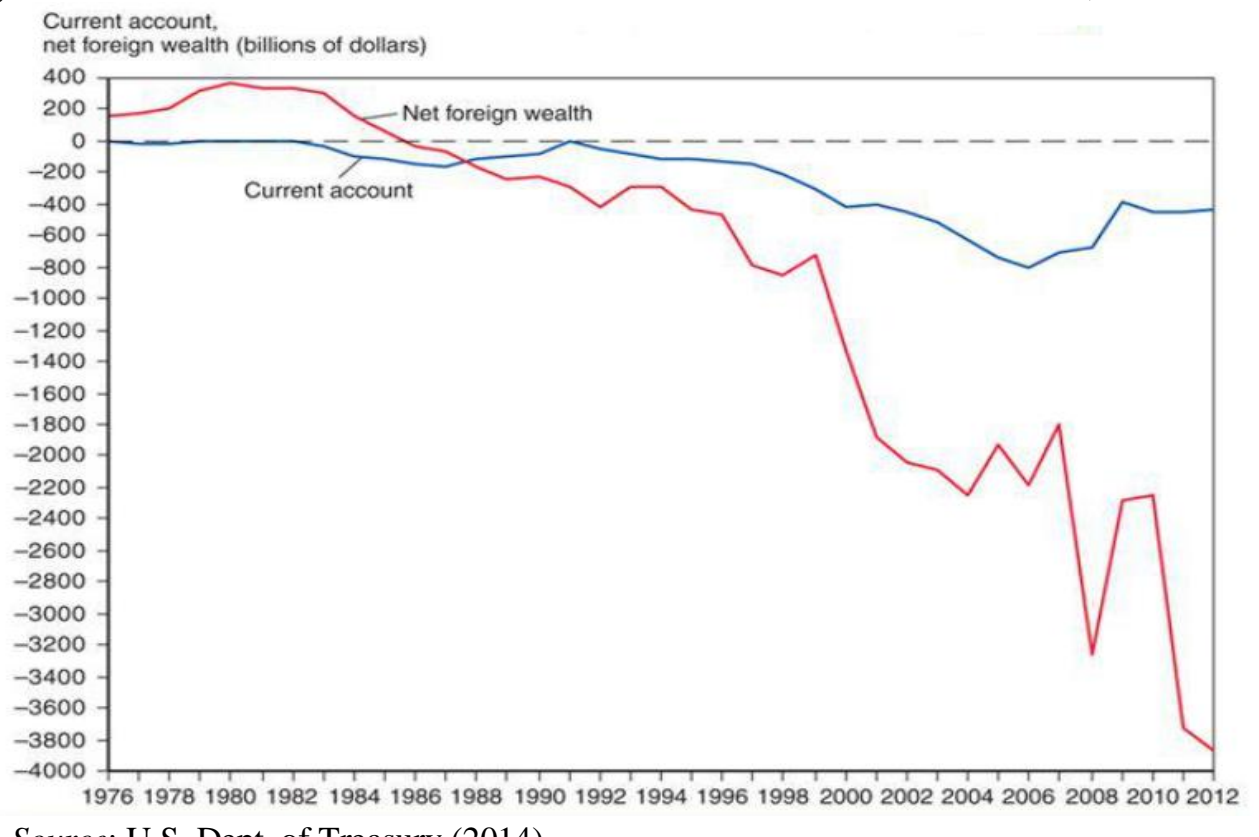

Source: U.S. Dept. of Treasury (2014)

projects that can be funded from the federal government. It has been proven that financing infrastructure projects using tax-exempt is not a cost-effective way of transferring revenues from the federal government to states and localities. For these reasons, other funding means are needed (Chappatta, 2015).

The U.S. has accumulated enough foreign debt that makes it difficult to allocate enough spending in the transportation sector. Figure 3 shows how a string of current account deficits can add up to become a large foreign debt. The U.S. has accumulated substantial foreign wealth since the early 1980s, when a sustained current account deficit of proportions opened up in the $20^{\text {th }}$ century for the first time. Its current account deficit in the first quarter of 2019 was $\$ 130.4-$ billion dollars, so that net of reign wealth continues to decrease (BEA, 2019). ${ }^{4}$ The value of

\footnotetext{
${ }^{4}$ In a seminal paper, Holmes and Panagiotidis (2009) used a flexible model to examine the behavior of the US current account through an examination of cointegration between imports and exports and asymmetries in the
} 
Figure 4. U.S Net International Investment Position at the End of the Quarter.

Billion \$
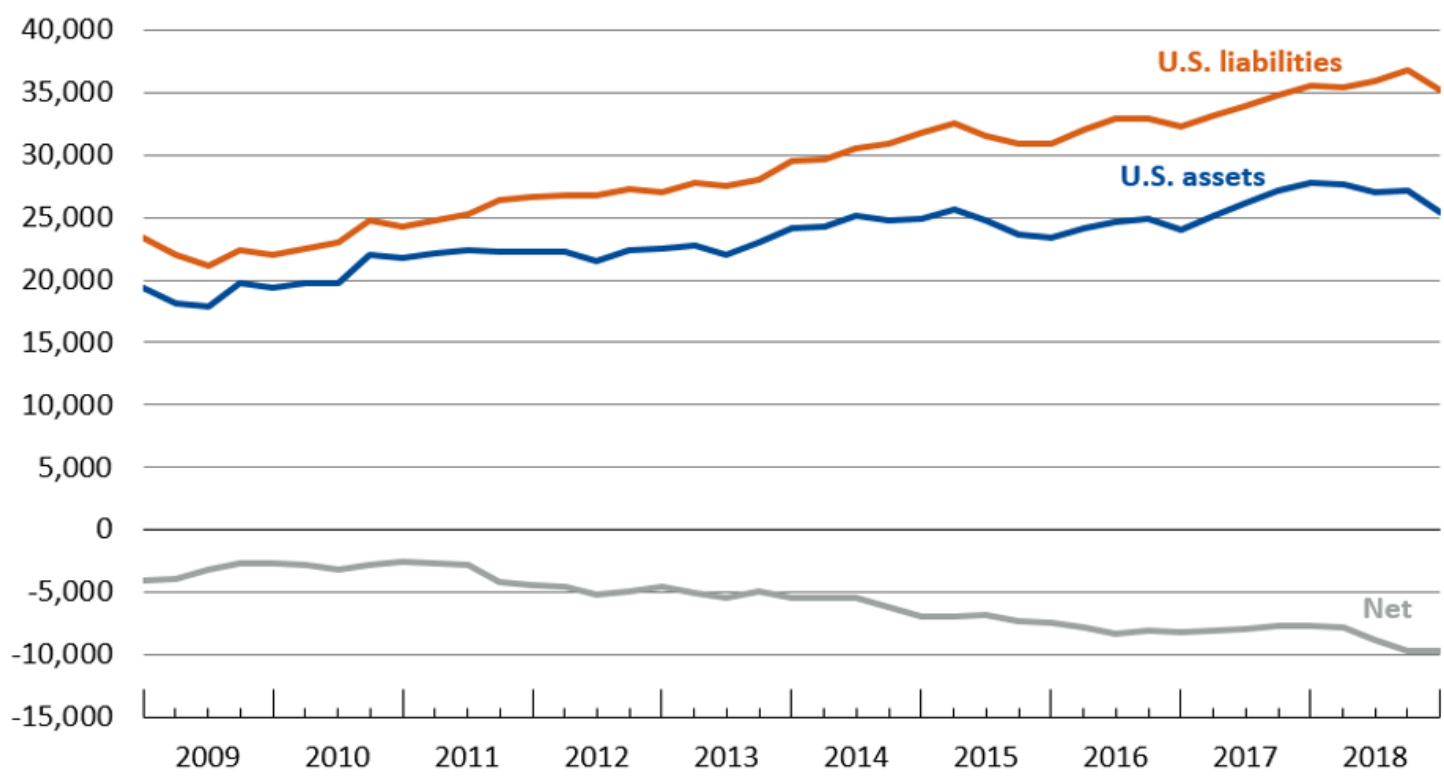

Source: BEA News (2019)

foreign investment in the U.S. increased more than the value of U.S. investment abroad, as seen in Figure 4. The value of foreign investments in the U.S. was raised by the increasing prices of U.S. treasury bonds and declines from foreign stock prices. This also lowered the value of U.S. investment abroad (BEA News, 2012). Most of the changes in the U.S. net international investment position are reflected on foreign acquisitions of U.S. assets that exceeded its acquisitions of foreign assets. ${ }^{5}$

\section{SWFs and their importance for U.S. infrastructure and economic growth}

SWFs have attracted a lot of investors in recent years, although they were first originated in 1953 by Kuwait Investment Authority. They are now defined as a state-owned pool of money from a nation's budgetary surplus that is invested in various financial assets such as infrastructure, rather than keeping it in banks (IWG, 2015). ${ }^{6}$

Investors of SWFs are among the few that can commit funds in the amounts and timeframes that infrastructure projects require. SWFs are part of sovereign savings, which include central bank reserves, commodity savings or stabilization funds, pension reserves or social security funds, and government holding management companies. SWFs have emerged as a new force in the global economic scene, with an estimated value of assets under management ranging from $\$ 3.5$ to $\$ 4$-trillion. ${ }^{7}$ It was argued that SWFs pursued different tactics from other groups

\footnotetext{
short-run dynamics of adjustment. The behaviour of the current account is used as an indicator of macroeconomic stability where concern has been expressed at the size of the US deficit. For many analysts, the behavior of the current account is used to reflect on the accumulation and sustainability of external debt as well as an indicator of potential exchange rate realignment. The paper found evidence in favor of cointegration through the application of the standard Johansen methodology.

${ }^{5}$ It is estimated that around $70 \%$ of foreign assets held by the U.S. are denominated in foreign currencies. However, the majority of U.S. liabilities (debt) are denominated in dollars.

6 The term "sovereign wealth fund" was credited in 2005 by Andrew Rozanov of State Street Corporation. Total assets under management of SWFs were \$1.5-trillion in 2005 and in 2018 they have grown to \$7.45 trillion worldwide across 78 funds (Preqin, 2015 and 2018).

${ }^{7}$ To put this number in perspective, the aggregate market capitalization of the Standard \& Poor's (S\&P) 500 and European stock exchanges is currently of the order of \$16-trillion. In recent years, the proliferation of new SWFs and the rapid growth of their assets have attracted much attention by the media, policymakers, and scholars.
} 
of capital and were suspect from the perspective of the global system. This is because they included their objectives as top priority rather than maximizing risk-adjusted returns and the ability to use government status to increase returns. This led to a debate on governance implications for recipients of SWF investments, which has culminated in the formulation of the 2008 Santiago Principles by the International Working Group (IWG) of SWFs.

These foreign government entities, or Global Public Investors (GPIs), have become increasingly powerful players in the world economy. Given the fact that U.S. has been running a deficit, the need for foreign investment has been increasingly high. According to the Congressional Research Service, foreign investment declined sharply after the investment of $\$ 300$-billion in U.S. businesses and real estate during the year 2000. In the aftermath of the financial crisis and recession, the U.S. has had pervasive capital needs for infrastructure development to enhance economic competitiveness, job creation, and technological innovation in order to fuel growth in the U.S. (Sabol and Puentes, 2015). ${ }^{8}$

Some countries have used long-term investment of SWFs to finance large infrastructure projects. For example, Asia needs eight-trillion dollars over the next ten years to finance infrastructure projects. As Lyons explains, "There is no surprise that Asia, along with Africa and Latin America, have been a key destination for sovereign funds in recent years. A number of sovereign funds, including those from China and the Middle East, are also allocating more funds to domestic infrastructure. Such investments are strategically beneficial for their own countries and commercially attractive for themselves, given the low risk and stable returns" (Lyons, 2014).

Ever since the Paris Climate Change Agreement came into effect in 2015, most investors have been focusing on projects to slow climate change. (Soddu and Barbary, 2019) Some countries, such as Norway and Spain, plan to shift to clean energy sources. The world's largest sovereign wealth fund is Norway's one trillion dollars in oil funds. It has started to use these funds into wind and solar power infrastructure projects. (Noceda, 2019) In addition, Spain delivered a plan on energy and climate which will allow $74 \%$ of energy to come from renewable sources by 2030. These projects will also attract major international investors. (Carrington, 2019)

Spending on transportation and water infrastructure has a positive impact on society since it can raise economic productivity and long-run economic growth. Better infrastructure can lower the cost of production and make firms more productive. Countries with high levels of labor productivity enjoy higher levels of long-run economic growth. SWFs have become more important for the global financial markets as they increase in size. According to the 2018 Preqin SWF Review, the total assets of SWFs top \$7.45-trillion as seen in Figure 5 (Preqin, 2018). Only a small portion of SWFs, about five-percent, is in the form of FDI. ${ }^{9}$

\section{Opportunities and concerns related to foreign investment for U.S. infrastructure}

New opportunities and benefits can arise by making better decisions on how to invest in infrastructure. It is important to note that real estate and infrastructure are the most favored asset classes by SWFs and the proportion of SWFs that invest in economic infrastructure is $58 \% .^{10}$

\footnotetext{
${ }^{8}$ Some examples of countries that leverage foreign investment in infrastructure and other projects to finance and advance critical national priorities include Canada, the United Kingdom and Australia.

${ }^{9}$ Evidence shows a clear growth trend since 2005 when SWFs invested a mere $\$ 7$ billion-despite a steep decline in annual flows in 2010 in response to global economic conditions. Also, FDI by SWFs in developed countries has grown faster than that in developing countries reflecting the availability of acquisition opportunities in North America and Europe during the crisis.

${ }^{10}$ FDI by SWFs, in developed countries, has grown faster than that in developing countries reflecting the availability of acquisition opportunities in North America and Europe during the crisis. In part, this reflects the strategic aims of the relatively few SWFs that are active in FDI, such as: Temasek (Singapore), China Investment Corporation, the Qatar Investment Authority and Mubadala (UAE).
} 
Figure 5. Aggregate SWF Assets under Management, 2008-2018

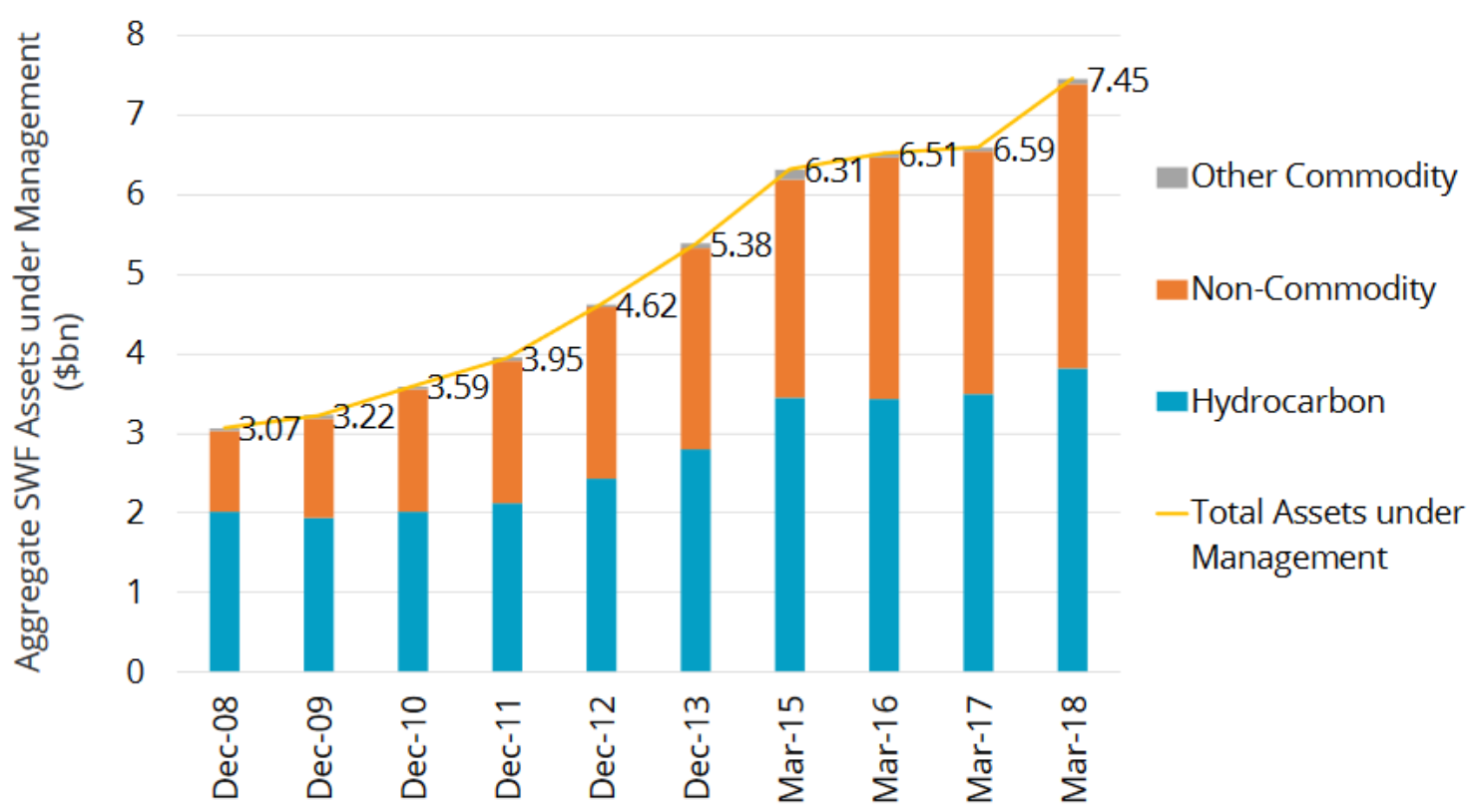

Source: Preqin (2018).

Even though SWFs and FDI are great vehicles in channeling foreign investment in U.S. infrastructure, they also embrace several concerns. The biggest concern with regards to SWFs in general has always been the fear of undue political motivation in foreign affairs and though funds report these non-controversial goals the lack of transparency from certain funds still causes many to question their true aims. Across regions, SWFs tend to exhibit different patterns of both investment and transparency. ${ }^{11}$ Another important concern that SWFs present is their lack of transparency and disclosure in terms of their investment portfolios. IMF's 2008 Santiago Principles encourages best practices, which has been adopted by 24 countries. The Peterson Institute of International Economics (IIE) and the SWF Institute created the Linaburg-Maduell Transparency Index to quantify SWF transparency and accountability. Both found that the largest funds (i.e., owned by the UAE, Qatar, Kuwait, and China) scored poorly.

Although conventional wisdom supports the philosophy that SWFs should limit domestic investment, a home bias in investment is observable in many SWFs. This home bias is particularly evident in Middle Eastern funds which also tend to be the most opaque of all SWFs. Balding (2012) argues that, due to their opacity and preference for investment in neighboring Arab nations, Middle Eastern SWFs have traditionally been considered the most threatening of all SWFs by many westerners and Americans in particular. However, Middle Eastern funds do possess foreign investments and generally exhibit sound growth and investment histories which indicate they are acting as purely financially motivated investors. Asian SWFs have also been considered threatening in the past and have a history of closer ties with government than any other SWFs by region. The China and Singapore funds have been considered particularly dangerous in the past for attempting to buy controlling stakes in companies, providing themselves with preferred home access, resisting foreign investment and using their funds as policy instruments.

\footnotetext{
${ }^{11}$ A case example is Dubai Port World (DPW), a state-owned company in the United Arab Emirates. DPW attempted to invest in America's shipping infrastructure and more specifically in ports. Its attempted investment raised the concern that DPW can influence the shipping routes and initiated a discussion about the national security risks of a foreign entity managing maritime trade hubs.
} 
All the above-mentioned concerns and risks have triggered the U.S. government to monitor the use of SWFs for its infrastructure purposes. For example, the recent attempts by a Chinese telecommunications giant to expand in the U.S. posed a national security threat according to a congressional investigation by the House intelligence committee. The investigation concluded that Huawei Technologies Inc. and ZTE Inc. posed security risks to the U.S. because their equipment could be used for spying on Americans. The committee recommended that the U.S. blocks acquisitions or mergers involving two companies through the Committee on Foreign Investments in the U.S. The report from the House intelligence committee concluded: "Huawei's failure to provide further detailed information explaining how it is formally regulated, controlled, or otherwise managed by the Chinese government undermines the company's repeated assertions that it is not inappropriately influenced by the Chinese government" (Gara, 2012).

As a result of this report, Sprint Nextel has dropped China's Huawei and ZTE from the shortlist for network expansion contracts potentially worth between $\$ 5$ and \$7-billion, following political pressure over claimed security issues. ${ }^{12}$ Huawei is the world's largest manufacturer of telecom equipment, making the losses for U.S. even bigger in terms of job creation and economic growth (Lublin and Raice, 2010).

\section{Conclusions and recommendations}

The U.S. faces a serious infrastructure investment problem. Its water and transportation infrastructure are nearing the end of its useful life. The American Society of Civil Engineers estimates that the U.S. needs to invest $\$ 4.59$ trillion by 2025 to maintain its current infrastructure in a state of good repair. With federal budget deficits and public debt expected to rise, there is a greater need for foreign investment. The current public resources are not sufficient to fit the bill. Other funding opportunities exist such as SWFs, but they present several challenges as well.. These funds are an important source of capital and can bring great benefits to the U.S. economy such as job creation.

SWFs have emerged as a new force in the global economic scene, with an estimated value of assets under management ranging from $\$ 3.5$ to $\$ 4$-trillion. They pursued different tactics from other groups of capital because they included their objectives as top priority and use government status to increase returns. In addition, Norway, the world's largest sovereign wealth fund of one trillion dollars, shifted the use of these funds into wind and solar power infrastructure projects.

It is desirable for global capital investment in the U.S to expand. There are examples of other nations, such as Australia, Canada, and the United Kingdom that leverage foreign investment in infrastructure to finance and advance critical national priorities. The U.S. should follow the successful partnership models from these countries in funding its infrastructure needs. In addition, based on the analysis in this paper, it is recommended that U.S. must create more favorable conditions and policies for FDI and attract Global Public Investors. Another important result is that the non-transparency element of SWFs can hinder the use of foreign capital for U.S. infrastructure. Evidence from IMF's 2008 Santiago Principles shows that the largest funds score poorly in terms of transparency. As such, a useful recommendation of this paper is that the U.S. should look for small funds for financing its infrastructure needs in order to minimize the risks and implications associated with the use of foreign capital for such purposes.

\footnotetext{
12 The House Intelligence Committee accused Huawei and ZTE of posing risks to U.S. national security because their equipment could become a vehicle for Chinese spying. The essence of the allegations against the company are that it has an undisclosed level of closeness to the Chinese government, which itself has an agenda to spy on the United States and potentially, should it be necessary, disrupt American telecommunications systems.
} 


\section{Acknowledgments}

For useful suggestions, we thank the editor, Professor Theodore Panagiotidis, three anonymous referees, and participants at: the 142 nd Annual Civil Engineering Conference in Montreal, Canada (2012) of the American Society of Civil Engineering, the 22 nd Business and Economics Society International Conference in Monte Carlo, Monaco (2013), and the 10 th International Conference on International Business in Thessaloniki, Greece (2019). We are also grateful to the seminar participants at King's College in PA, USA.

\section{References}

American Society of Civil Engineers (ASCE) (2017) 2017 report card for America's infrastructure, available via: https://www.infrastructurereportcard.org/americas-grades/, accessed October 2019.

Balding, C. (2012) Sovereign wealth funds: the new intersection of money and politics, New York: Oxford University Press.

Balin, B. J. (2008) Sovereign wealth funds: a critical analysis, Social Science Research Network, available via: http://papers.ssrn.com/sol3/papers.cfm?abstract_id=1477725, accessed July 2015.

Bureau of Economic Analysis (BEA) (2019) U.S. current-account deficit decreases in first quarter 2019, U.S. Department of Commerce, available via: https://www.bea.gov/news/blog /2019-06-20/us-current-account-deficit-decreases-first-quarter-2019, accessed November 2019.

Bureau of Economic Analysis (2012) Value of foreign investment in the U.S. increased more than value of U.S. investment abroad in 2011, U.S. Department of Commerce, available via: http://blog.bea.gov/2012/06/26/international-investment-2011/, accessed June 2015.

Carrington, D. (2019) Historic breakthrough: Norway's giant oil fund fives into renewables, The Guardian, available via: https://www.theguardian.com/environment/2019/apr/05/ historic-breakthrough-norways-giant-oil-fund-dives-into-renewables, accessed January 2020.

Council on Foreign Relations (2012) Federal transportation infrastructure policy, renewing America progress report and scorecard, available via: www.cfr.org/content/publications /.../Infrastructure_Progress_Report.pdf, accessed June 2015.

Congressional Budget Office (CBO) (2018) Public spending on transportation and water infrastructure: 1956 to 2017, Congressional Budget Office, Washington, DC, available via: https://www.cbo.gov/system/files/2018-10/54539-Infrastructure.pdf, accessed on October 2019.

U.S. Energy Information Administration (EIA) (2019) How much tax do we pay on a gallon of gasoline and on a gallon of diesel fuel?, available via: https:/www.eia.gov/tools/faqs/ faq.php?id=10\&t=10, accessed November 2019 .

Holmes, M. J., and Panagiotidis, T. (2009) Cointegration and asymmetric adjustment: some new evidence concerning the behavior of the U.S. current account, The B.E. Journal of Macroeconomics, 9(1), 1-25.

Gara, T. (2012) On questions of national security, is Huawei innocent until proven guilty?, The Wall Street Journal, available via: http://blogs.wsj.com/corporate-intelligence/2012/10/08/ on-questions-of-national-security-is-huawei-innocent-until-proven-guilty/, accessed October 2015.

Lyons, G. (2014) A growing role for sovereign wealth funds, McKinsey on Society, International Working Group of Sovereign Wealth Funds, available via: http://www.iwgswf.org/, accessed September 2015. 
Kirkpatrick, C., Parker, D. and Zhang, Y. F. (2006) Foreign direct investment in infrastructure in developing countries: Does regulation make adDifference?, Transnational Corporations, 15 (1).

Lublin, J. S., and Raice, S. (2010) Security fears kill Chinese bid in U.S., The Wall Street Journal, available via: http://www.wsj.com/articles/SB100014240527487043535045755 96611547810220 , accessed October 2015.

Noceda, M. A. (2019) Spain hopes to attract Norwegian investment to its renewable energy projects, El Pais Newsletter, available via: https://elpais.com/elpais/2019/06/14/inenglish /1560523979_937948.html, accessed January 2020..

Preqin (2018) Preqin special report: sovereign wealth fund, available via: https://docs.preqin .com/reports/Preqin-Special-Report-Sovereign-Wealth-Funds-August-2018.pdf, accessed October 2019.

Sabol, P., and Puentes, R. (2015) Building better infrastructure with better bonds, Brookings Report, available via: http://www.brookings.edu/research/papers/2011/03/11-sovereignwealth-funds, accessed June 2015.

Sander, L., and Saulny, S. (2007) Bridge Collapse in Minneapolis Kills at Least 7, New York Times, available via: http://www.nytimes.com/2007/08/02/us/02bridge.html?_r=0, accessed June 2015.

Soddu, E., and Barbary, V. (2019) Sovereign wealth funds get creative in infrastructure, Investment strategies for the world's largest institutional investors, available via: https://www.top1000funds.com/2019/07/swfs-get-creative-in-infrastructure/, accessed January 2020.

White House (2019) Available via https://www.whitehouse.gov/wp-content/uploads/2018/02/ 27-1-fy2019.pdf, accessed October 2019. 